PROBLEMS

OF EDUCATION IN THE $21^{\text {st }}$ CENTURY Vol. 78, No. 5, 2020

832

\section{DEVELOPMENT OF A CHILDREN QUESTIONNAIRE FOR MEASURING CHINESE CHARACTER LITERACY LEARNING SATISFACTION}

\author{
Shiat Lu Wong, Nyet Moi Siew, Chiow Thai Soon \\ University Malaysia Sabah, Malaysia \\ E-mail: wongshiatlu@gmail.com, sopiah@ums.edu.my, soon@ums.edu.my
}

\begin{abstract}
There are limited reports about development of questionnaire to measure learning satisfaction among young children. In this research, guidelines were listed for developing a questionnaire that gauges Chinese Character Literacy Learning Satisfaction (CCLLS) among 8-year-old children. The research was undertaken based on the responses of 232 children from 11 Chinese national type primary schools (SJKC) of Kota Kinabalu, Sabah, Malaysia. The CCLLS questionnaire consists of 12 items developed through three dimensions of satisfaction, which are (1) Satisfaction towards Chinese characters writing, (2) Satisfaction towards Chinese characters recognizing, (3) Satisfaction towards the learning in classroom. Rasch analysis was used to examine the item polarity. The result showed point measure correlation was within $0.47-0.60$. The items were also detected with the outfit mean square in the range of $0.76-1.24$, indicating CCLLS was fit to measure the children's learning satisfaction. The raw variance explained by measures (33.3\%), the unexplained variance in first contrast $(9.1 \%)$, with the eigenvalue $(1.6 \%)$ from the principal component analysis, suggested that CCLLS could be unidimensional. The internal consistency was considered very high with 0.81 in Cronbach's alpha (KR-20). The result also showed CCLLS has very good item reliability (0.91) with good item separation index (3.23). The person reliability (0.77) was in satisfactory range with moderately good person separation index (1.81). The findings indicated that CCLLS questionnaire could be a valid and reliable tool in measuring Chinese character literacy learning satisfaction among 8-year-old primary school children of SJKC.
\end{abstract}

Keywords: children questionnaire, Chinese Characters Literacy Learning Satisfaction, Rasch analysis, validity and reliability

\title{
Introduction
}

Literacy in Chinese characters is the foundation of learning Chinese language. There are two skills in Chinese character literacy: 1) Recognizing the Chinese characters - pronouncing Chinese characters phonetically correct and understanding the general meaning of that character; 2) Writing Chinese characters - producing Chinese characters by following the correct structures and strokes (Curriculum Development Division, 2016). According to Malaysian standardized curriculum by the Ministry of Education (MOE), one of the learning objectives of the Chinese language subject is mastering 2500 Chinese characters and being able to write the characters in an intelligible way with correct writing structure.

The national curriculum of Malaysia is an educational program that is grounded based on the national education philosophy. The characteristics that are created in an individual who 
Shiat Lu WONG, Nyet Moi SIEW, Chiow Thai SOON. Development of a children questionnaire for measuring Chinese character literacy learning satisfaction

PROBLEMS

OF EDUCATION

IN THE $21^{\text {st }}$ CENTURY

Vol. 78 , No. 5, 2020

receives education must base on a clear philosophy, specifically a philosophy that is the core of the nation's education (Alhabshi \& Hakim, 2001). In tandem, the impact of emphasizing the 833 learning of Chinese character literacy based on the curriculum that comprises knowledge, skills, morals and values can fully develop students physically, spiritually, mentally and emotionally to inculcate moral values (National Curriculum, 1997). The result of learning Chinese character literacy after an intervention can be evaluated by using the questionnaire on Chinese Character Literacy Learning Satisfaction (CCLLS) among the school children. Figure 1 illustrates the evaluating concept.

\section{Figure 1}

Conceptual framework of evaluating Chinese character literacy learning satisfaction

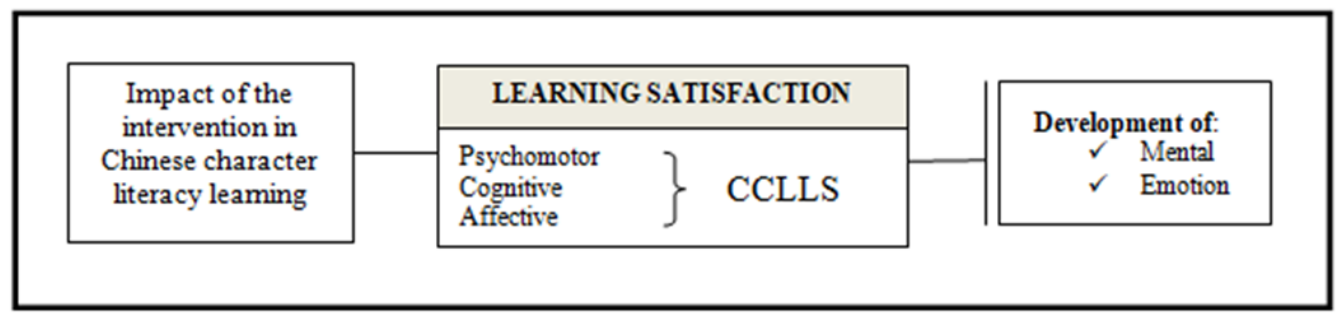

Evaluating children's learning satisfaction comprises aspects of mental and emotion as illustrated in Figure 1. Completing a self-administered questionnaire always involves a question-answer process. During the process, the children characteristics usually influence the task performance. Completing a question-answer task often makes a young child mentally and emotionally engaged in the process, thus it is a learning process. Firstly, the children have to understand the question and to define the intended meaning of the question. It is followed by retrieving the relevant information from their memory to form a tentative answer. Then, the children have to make an appropriate response and to choose the response option according to the answer formulated in their mind before. During the process of choosing a response, the children would 'edit' their answers according to the social desirability or condition tolerability. Children may behave contrary before their teachers, parents and peers (Borgers et al., 2000), which would result in the suggestibility of their answers. The effort made for overcoming these specific age-reliant problems can yield an outcome of a quality CCLLS questionnaire.

\section{Research Problem}

A questionnaire can give a full picture about a system besides showcasing the specifics of a scenario (Lewis, 1995). Questionnaires are always used to measure the satisfaction of consumers towards a product. In the context of education, the effectiveness of an intervention can be tested from learners' satisfaction in the learning situation that practices such intervention (Che Nidzam et al., 2010). Nonetheless in reality, the effectiveness of intervention in the teaching and learning process is usually evaluated with tests that focus solely on the expansion of knowledge and cognitive skills. The affective value like learning satisfaction is commonly treated as an unimportant by-product. Lack of suitable tools to evaluate children's learning satisfaction is one of the reasons why learning satisfaction is considered unimportant. Based on a pioneer study, the researcher found that the do-ability of questionnaires for primary school children is always questioned due to their age and poor experience. Thus, a suitable and quality questionnaire is in deem needed. To overcome the problem mentioned, the questionnaire needs to be kid-friendly and have easy to understand language. Additionally, emoji digital images 
Shiat Lu WONG, Nyet Moi SIEW, Chiow Thai SOON. Development of a children questionnaire for measuring Chinese character literacy learning satisfaction

OF EDUCATION

IN THE $21^{\text {st }}$ CENTURY

Vol. 78, No. 5, 2020

can be used as a 5-point Likert scale in the questionnaire to make it easy for the 8-year-old respondents to choose the appropriate responses to reflect their perceptions. The questionnaire that is improvised based on these requirements needs to be authenticated and validated through a research.

\section{Research Focus}

The main focus of this research was to develop a questionnaire on Chinese Character Literacy Learning Satisfaction (CCLLS) for 8-year-old children in primary schools. Validity and reliability are two important factors to be considered when developing a questionnaire. Hence for the need to develop a valid and reliable tool, Rasch analysis was used to examine the validity and reliability of CCLLS questionnaire.

\section{Learning Satisfaction}

The effectiveness of a reinforcing method does not necessarily depend on the frequency of practice alone (Anderson, 1996), thus the significance of the research of reinforcement must be seen from various perspectives. Psychological factors such as interest, motivation and emotion have an impact on an individual's memory capabilities (Kenny, 1985). For example, learners' memory power is affected negatively because of their disinterest in learning due to having too many and tedious writing practices. Reinforcement is part of the learning process; thus, its effectiveness may yield learning satisfaction to learners from cognitive, psychomotor and affective view.

A fun teaching and learning process will have an impact on learners' satisfaction, especially among primary school students between ages seven to twelve years old. According to Anderson et al. (1994), satisfaction is an important indicator for past, present and future performance. Satisfaction towards a product is usually evaluated after the product or service is supplied. In the context of education, a learner's satisfaction is influenced by the learning quality in the classroom, or the method suitability used by the teacher (Guolla, 1999). In lieu of this, if the classroom environment or teaching material is excellent, then the learners' learning satisfaction is formed and has an impact on their attitude (Kim et al., 2000). As a result, learning satisfaction improves the learners' performances as a whole (Hamed et al., 2008). Learning is important to students. According to Zhu (2008), learning satisfaction is a part of a sense of well-being in students' learning. All the efforts done to improve the quality of classroom teaching and learning will bring learning satisfaction that upholds the students' sense of wellbeing, as illustrated in Figure 2.

\section{Figure 2}

Sense of well-being in learning

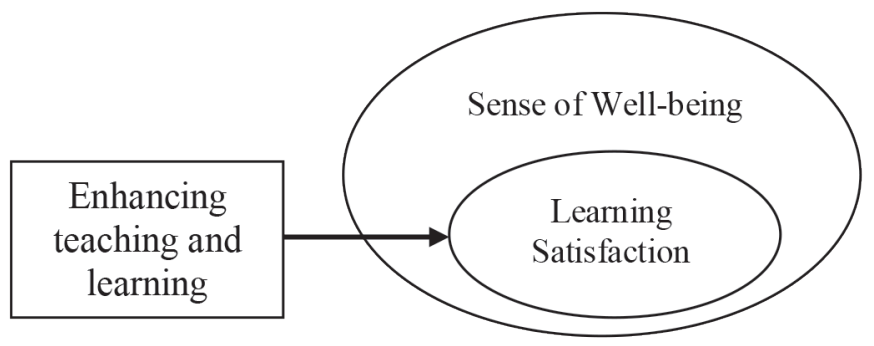


Learners' and teachers' satisfaction towards the learning process is an indicator which

PROBLEMS

OF EDUCATION

IN THE $21^{\text {st }}$ CENTURY

Vol. 78 , No. 5, 2020

is often used in an education evaluation program or in an innovative effort (Zandvliet, 1999). In the context of this study, the level of satisfaction is divided into three clusters based on the educational objectives of Bloom's Taxonomy. The students' satisfaction towards a reinforcement method in Chinese character literacy in this research refers to the learning satisfaction of the 8-year-old children in Malaysia Chinese national type school. Three clusters of learning satisfaction were engaged in the survey which were categorized into the domains of: 1) Psychomotor refers to students' satisfaction to the result of writing reinforcement; 2) Cognitive refers to students' satisfaction towards recognizing the Chinese characters as the result of the writing reinforcement; 3) Affective refers to students' satisfaction in learning Chinese character literacy in the classroom. Based on the study of Dong (2006), the literacy learning of Chinese characters is a cognitive schema building process that enables students to adapt to the structure of Chinese characters (cognitive domain). An efficient psychomotor is necessary for the students to transform their memory and understanding about a Chinese character's structure to the written form. This process only occurs with the mastery of writing which involves the coordination of small-muscle and eyes, known as fine-motor skill. Consequently, a learner needs to have interest, courage and the will to learn in the process of writing Chinese characters, which can be classified as affective domain.

Bloom's Taxonomy is a hierarchy model that is used in classifying the learning objectives based on the specification which encompass the domains of cognitive, affective and sensory (or more commonly known as psychomotor). The psychomotor domain includes coordination and use of the fine-motor skill (Simpson, 1972).

\section{Satisfaction: Dimension of Writing}

Mastery in the skill of writing Chinese characters in the schools of Chinese national type primary school (SJKC) in Malaysia is set based on the learning objectives that are stated in the Document of Standardized Curriculum and Assessment (DSKP). Writing Chinese characters correctly and neatly is a general objective. Wang (2011) stated that mastery in psychomotor skills to write Chinese characters is a type of learning behavior. Teachers will facilitate their students to sit in proper position while writing, including the correct way of handling a pencil. These are required to ensure that the practice of correct and good writing is inculcated in early schooling years. A good practice of writing would help students to produce accurate and tidy writing, where the hand and eye coordination is engaged in the process. In a piece of neat and well-structured writing, a student has to write with the correct strokes (笔画) and to make sure of the proper placement of the components in the square tian box (田字格). These are learnt and facilitated through imitating the mannerisms of the correct writing way (Zhang, 2016). The learning process through adaptation and amalgamation between imitating mannerisms and the individual experience can be considered as a psychomotor learning (Simpson, 1972). Li (2019) asserted that psychomotor learning in writing Chinese characters comprises three stages, which are cognitive, associative and autonomous. The skill acquisition was proposed by Fitts and Posner (1967) which is visualized in Figure 3. 
Shiat Lu WONG, Nyet Moi SIEW, Chiow Thai SOON. Development of a children questionnaire for measuring Chinese character literacy learning satisfaction

PROBLEMS

OF EDUCATION IN THE $21^{\text {st }}$ CENTURY Vol. 78, No. 5, 2020

Figure 3

Model of skill acquisition (Fitts \& Posner, 1967)

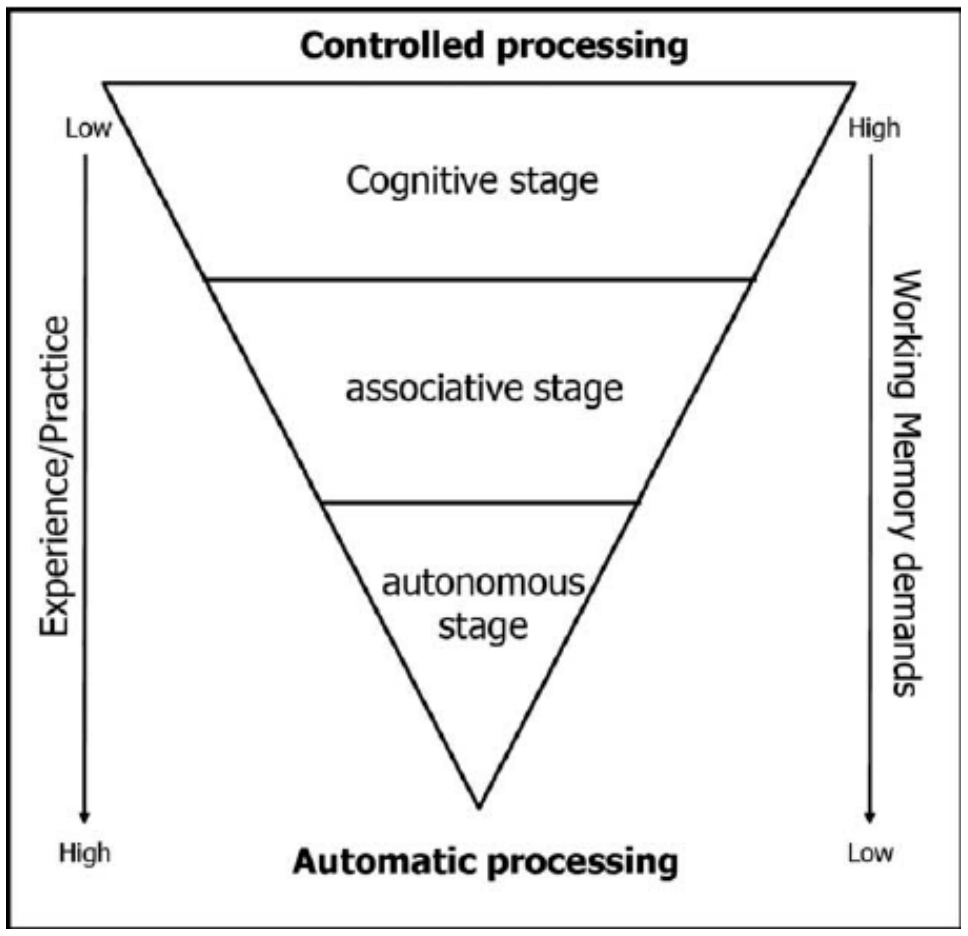

After learning the Chinese characters through the teaching and learning process in the classroom, the students would have to practice the procedure by writing step by step after observing the tips or rules in creating strokes. Through practice, students will be adept in writing Chinese characters easily and smoothly. This is based on the experience they gain from the associative stage (Figure 3). The augmentation of writing practice of Chinese characters needs to be fortified to ensure that each writing process can be done in an easy, smooth and speedy manner. By doing so may result in autonomous writing skill. At this stage, a student can remember a Chinese character without having to think too hard about it (Li, 2019; Zhang et al., 2017). When this stage is achieved, the student is considered to have achieved or mastered the autonomous skill of writing Chinese characters. Satisfaction in achieving this stage is gauged in the Dimension of Writing.

\section{Satisfaction: Dimension of Recognizing Chinese Characters}

Chinese character, also known as Hanzi (汉字) is logographic in nature. Each Chinese character has a featured shape (形), sound (音), and meaning (义). As an example, the meaning of the character 人 is human, the pronunciation and sound of the character 人 is rén, and the structure of 人 consists of two strokes (笔画). Each Chinese character has a structure, sound and meaning, thus the Chinese language is categorized as an ideographic language in linguistic classification. The learning in Chinese language is different from the learning of other languages such as English that the alphabet usually takes place to form a word (Zhang, 2006). Every Chinese character is unique and has its pictographic attributes. Hence, the learning of Chinese character is a complex psychological process that involves the construction of structure, sound and meaning in understanding a piece of writing (Dong, 2006). Figure 4 shows this psychological construction. 


\section{Figure 4}

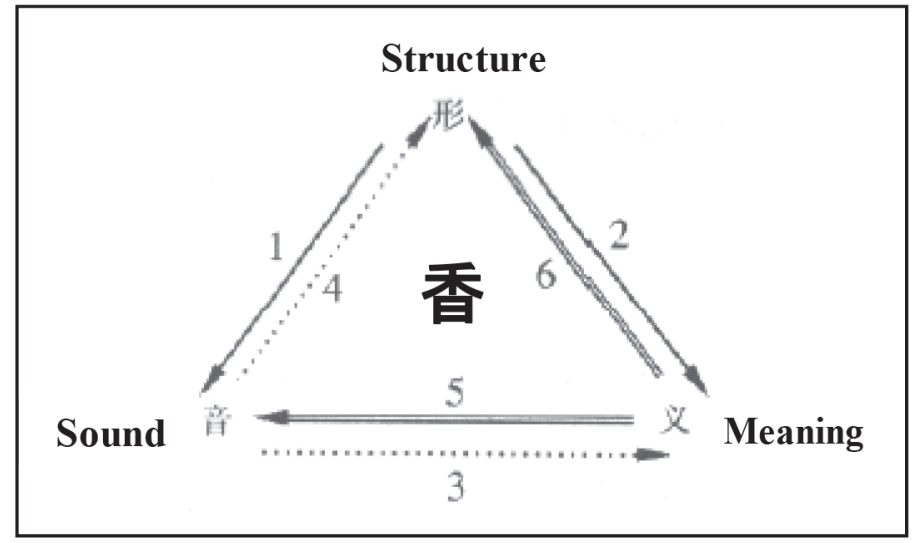

For example, when recognizing the character 香, it is known that its pronunciation is 'xiāng' and its meaning is 'fragrant' in English. The schema of the six psychological constructions is demonstrated in Figure 4, followed by the elaborations:

$1^{\text {st }}$ construction: Observe at the structure of character is 香, know how to pronounce the sound of 香 as 'xiāng'.

$2^{\text {nd }}$ construction: Observe the structure of character 香, know the meaning of 香 is $3^{\text {rd }}$ construction: $\quad$ Hear the sound 'xiāng', know the meaning is 'fragrant'.

$4^{\text {th }}$ construction: Hear the sound 'xiāng', recognize the structure is 香.

$5^{\text {th }}$ construction: Intend to say the meaning as 'fragrant', know how to pronounce the $6^{\text {th }}$ construction: $\quad$ Intend to say the meaning as 'fragrant', recognize the structure of the 香, including the character of 香 is constructed by having 禾 as the top component and 日 as the bottom component, and able to write the character as 香.

In this research, the Chinese character literacy learning intervention was introduced to help the students understand a Chinese character in all rounded six psychological constructions. A student will gain satisfaction in learning if they could understand a piece of Chinese character based on one of the psychological constructions proposed by Dong (2006). Writing practice will reinforce the process of $6^{\text {th }}$ construction. The learning satisfaction towards the $2^{\text {nd }}$ and $6^{\text {th }}$ constructions was particularly evaluated in the Dimension of Recognizing Chinese character.

\section{Satisfaction: Dimension of Classroom Learning}

Evaluation is essential in the drilling of writing Chinese characters. Besides the evaluation conducted by the teacher, students can also make self-evaluation towards their writing. Optimum success in learning can be achieved through self-efficacy (Bandura, 1997). Self-efficacy is an individual's confidence in their own capability to act on something till it succeeds (Ardiyanti, 2016). Self-evaluation towards writing Chinese characters is a form of self-efficacy ( $\mathrm{Li}, 2019$; Wang, 2011). Students learn how to write Chinese characters based on the instructions given 
Shiat Lu WONG, Nyet Moi SIEW, Chiow Thai SOON. Development of a children questionnaire for measuring Chinese character literacy learning satisfaction

PROBLEMS

OF EDUCATION IN THE $21^{\text {st }}$ CENTURY Vol. 78 , No. 5, 2020

838

by their teachers during lessons. Besides, they also make their own effort to imitate good writings with the hope of being able to produce good writing. That is why Chinese character writing practices can incur satisfaction not only from a psychomotor and cognitive view, but also satisfaction in the affective domain that comprises moral values such as patience, courage and self-esteem. In CCLLS, affective satisfaction is measured specifically in the Dimension of Classroom Learning. The affective domain is also placed as an overall component for all the satisfaction dimensions that are studied under the CCLLS survey.

\section{Questionnaire in Children Survey}

CCLLS questionnaire is concerning children's learning, thus careful pre-testing was necessary to determine if the self-administered task was feasible for 8-year-old children. According to De Leeuw (2011), children aged between 7 to10 can be surveyed directly. The question-answer process is crucial to a successful survey. When surveying children, we should understand that the cognitive growth of the children has deep repercussions for the questionanswer process. The development of this early middle childhood stage is labelled as development of concrete operations according to Piaget's theory of cognitive growth. These children begin to differentiate dissimilar points of view, but this is still far from faultless. They still do have problems with logical customs, for instance with negation. Children of this stage are still very literal in the interpretation of words and experience the same problem as younger children with indirect questions (Borgers et al., 2000). In the construction of CCLLS, the researcher had examined very carefully all the items through a pre-test based on the guidelines listed by De Leeuw (2011). The findings of the pre-test were summarized with some practical suggestions for producing a quality questionnaire in children survey:

(1) The language used in both items and instructions in CCLLS questionnaire were simple. The item wording was made to be clear, concrete, explicit and unambiguous. For example, the statement “我可以专心地练习写字” (English equivalent: I can focus when doing the writing practice) might not be easily understood by the young children. The researcher rephrased the statement as “我可以静静地坐着写字” (English equivalent: I can sit quietly when doing the writing practice), which has the same intended meaning of 'focus'. Both items and instructions were presented in clear language, at a level that 8-year-old school children can understand.

Due to the memory capacity and the memory speed still developing in the early middle childhood (aged 7 to 12), the researcher tried to avoid or lessen retrospective statements. The questionnaire had been executed as soon as possible, even right after the intervention. This was in regard to the difficulties for a young child to clearly recollect events. Besides, the reference period has to be well defined in the question by using 'here and now' statement as stressed by Amato and Ochiltree (1987). For example, the researcher specified '最近' (English equivalent: lately) for the first item: “最近我比较喜欢写字” (English equivalent: I have been enjoying the writing activity lately). In order to keep the task short and attractive, the complication of the statements and the number of response categories had been carefully checked. The researcher found that using emoji digital images as 5-point Likert scale was very helpful, as these kid-friendly faces could arouse visual stimuli for the young children and could make the response options more concrete and interesting.

(3) Children in early middle childhood were prone to please their teachers by not expressing their own thoughts and feelings (Borgers et al., 2000; De Leeuw, 2011). To be wary of 
this potential problem, the researcher reversed the direction of some questions to reduce response bias. For example, instead of asking the children's own feeling: “你喜欢上华 IN THE $21^{\text {st }}$ CENTURY Vol. 78 , No. 5, 2020 文课吗?" (English equivalent: Do you like taking Chinese lessons?), the researcher reduced the effect of tendency to agree with the presented statement by asking: “班上 的同学喜欢上华文课吗?” (English equivalent: Do you think your classmates like taking Chinese lessons?). The children would say "yes" if they personally like to take Chinese lessons and would say "no" if they don't.

According to Borgers et al. (2000), how well the children can understand what they read influenced the consistency of their responses. In regard to the reading ability and short attention span which would affect the data quality of CCLLS questionnaire, the researcher used active board with power point as an aid to present the items. Each item was presented in single slide, and the total number of items was minimized to twelve. The researcher also read aloud the items to prevent the children's literacy problem. By displaying the items auditory in attractive slides, problems with lack of motivation and difficulties in keeping up concentration of the young children could be minimized.

(5) It is important to keep the sentence clear and short in a questionnaire. If the meaning of a statement was not clear or ambiguous, young children tend to construct scripts according to the events they are familiar with to hide that they do not understand. In a paper questionnaire, a child can easily skip a question by mistake or by intention when they feel bored with the long questions (Borgers et al., 2000). This would cause missing data and would affect the data quality of a questionnaire. Therefore, the researcher made sure each item of CCLLS was specified in one single sentence, and each sentence consisted of not more than eleven characters (words). The researcher also used the age-relevant terms for the items. Despite proper use of formal terms is crucial in a questionnaire, the researcher still made an effort to consider the words that are more children-friendly. For example, the young children might not understand or get used to the term习字 (English equivalent: writing practice). Thus, it was substituted with the children's daily-use wording: 练习写字 (English equivalent: doing writing exercise).

\section{Research Aim and Research Questions}

This research was aimed to develop a valid and reliable children questionnaire for measuring the Chinese character literacy learning satisfaction among the Year Two students of the primary schools. There were three research questions to be answered:

Q1: Is the survey on learning satisfaction of 8-year-old children feasible by using CCLLS self-administered questionnaire?

Q2: What is the construct validity of CCLLS questionnaire in measuring the Year Two students' learning satisfaction in writing Chinese characters, recognizing Chinese characters, and classroom learning based on: 1) Item statistics; 2) Confirmation of dimensionality?

Q3: How reliable is the questionnaire in measuring the satisfaction of Chinese character literacy learning among Year Two students according to: 1) KR-20 Cronbach's coefficient alpha; 2) Person and item reliability indices? 
Shiat Lu WONG, Nyet Moi SIEW, Chiow Thai SOON. Development of a children questionnaire for measuring Chinese character literacy learning satisfaction

\author{
PROBLEMS \\ OF EDUCATION \\ IN THE $21^{\text {st }}$ CENTURY \\ Vol. 78, No. 5,2020 \\ 840 Research Methodology
}

\title{
General Background
}

Malaysia is a multi-racial country. There are national schools, Chinese or Tamil national type schools, and private schools that parents can enroll their children in getting primary education. Primary education takes six years and is a continuation of pre-school education. Children usually start primary school when they are 7 years old. The research was conducted in Chinese national type primary schools of Kota Kinabalu district, state of Sabah in Malaysia. Before the CCLLS questionnaire was administered, an intervention of Chinese character literacy learning was executed. The respondents were engaged in the learning activity on one unit of Chinese character literacy from the textbook, which is published under the Chinese National Type Primary School (SJKC) curriculum series by Ministry of Education in Malaysia. Then, it was followed by a reinforcement of writing activity. CCLLS questionnaires were distributed to the respondents the next day after they were assessed with a literacy test to examine the outcome of the intervention. The data collected from the administration of CCLLS questionnaire was used to reflect the children's satisfaction through their subjective evaluation towards the outcome of Chinese character literacy learning.

\section{Sample}

In Malaysian education system, the lower primary, which is Year One, Two and Three are the core levels in learning Chinese characters. Year Two children of SJKC were targeted in this research because the children at this level had been learning Chinese characters for at least twelve months. The researcher also assumed that the Year Two children were to be better in giving their responses and perceptions towards Chinese character literacy learning, if compared to Year One.

There are eleven Chinese national type primary schools (SJKC) at the research site. The population of the Year Two students studied in SJKC was 556. According to Linacre (1994), the minimum sample size of 30 participants is enough to create accurate and consistent data at a 95\% confidence in Rasch analysis. Sample size in the range of $108-243$ is considered to be large enough to provide $99 \%$ confidence that item difficulty can be estimated within $\pm 1 / 2$ logit of its stable value (Linacre, 1994). This research had a sample size of 232, with 119 males (51\%) and 113 females (49\%) aged between $7-8$ years old, chosen randomly from eleven SJKC. All the samples had been studying Chinese language subject under the curriculum of Malaysia. In this research, the samples would turn to be the respondents of CCLLS questionnaire after participating in the scheduled Chinese character literacy learning intervention.

\section{Research Scope, Method and Duration}

This research was to survey the learning satisfaction of 8-year-old students in Chinese character literacy, which was attached to an intervention focused on Chinese character writing reinforcement. The data was collected and analyzed in quantitative method. There were four steps involved in developing CCLLS questionnaire: 1) Concept identification; 2) Item formulation; 3) Pre-testing questionnaire; 4) Validity and reliability test. Prior to the item construction which began from June 2019, an overview of the philosophy on learning 
Shiat Lu WONG, Nyet Moi SIEW, Chiow Thai SOON. Development of a children questionnaire for measuring Chinese character literacy learning satisfaction

PROBLEMS

OF EDUCATION

IN THE $21^{\text {st }}$ CENTURY

Vol. 78 , No. 5,2020

satisfaction, and objectives of the national curriculum was made through a literature review. It was followed by comparing the learning objectives of Chinese character literacy with the main focus on the national curriculum. The conceptual characteristics that shared by both the learning objectives of Chinese character literacy and the national curriculum were identified precisely before it was applied in CCLLS questionnaire item formulation. Item pre-testing was conducted from 9 to 23 July 2019. The construct of CCLLS questionnaire was modified and the items were refined during this period. It was followed by the first pilot study (5 August 2019), and the second pilot study (17 September 2019). The CCLLS questionnaire administration in the true research commenced on 7 October 2019 and ended on 10 October 2019.

\section{Instrument and Procedures}

\section{Instrument}

The data collected from the administration of CCLLS questionnaire was based on children's experiences throughout the Chinese character literacy learning process, which was categorized in the domains of psychomotor, cognitive and affective. The development of the CCLLS questionnaire was related to the learning objective classification of Bloom's Taxonomy as shown in Table 1.

\section{Table 1}

Framework of CCLLS Questionnaire construction

\begin{tabular}{|c|c|c|c|c|c|}
\hline $\begin{array}{l}\text { Construct: } \\
\text { Item }\end{array}$ & $\begin{array}{l}\text { Dimension of } \\
\text { Satisfaction }\end{array}$ & $\begin{array}{l}\text { Item } \\
\text { (Presented with an example) }\end{array}$ & $\begin{array}{l}\text { Domain } \\
\text { Psychomotor }\end{array}$ & Cognitive & Affective \\
\hline $\begin{array}{l}\text { A: } \\
\text { A1 }-\mathrm{A} 4 \\
\text { (4 items) }\end{array}$ & $\begin{array}{l}\text { Children's } \\
\text { satisfaction towards } \\
\text { their learning in } \\
\text { writing Chinese } \\
\text { character after the } \\
\text { intervention }\end{array}$ & $\begin{array}{l}\text { A4:我看到自己写的字很开心 } \\
\text { (I am happy when looking at my } \\
\text { own writing) }\end{array}$ & $\sqrt{ }$ & & $\sqrt{ }$ \\
\hline $\begin{array}{l}\text { B: } \\
\text { B5 - B9 } \\
\text { (5 items) }\end{array}$ & $\begin{array}{l}\text { Children's } \\
\text { satisfaction towards } \\
\text { their learning in } \\
\text { recognizing Chinese } \\
\text { characters after the } \\
\text { intervention }\end{array}$ & $\begin{array}{l}\text { B9:我会认书里的很多字 } \\
\text { (I can recognize many Chinese } \\
\text { characters in a book) }\end{array}$ & & $\sqrt{ }$ & $\sqrt{ }$ \\
\hline $\begin{array}{l}\text { C: } \\
\text { C10 }- \text { C12 } \\
\text { (3 items) }\end{array}$ & $\begin{array}{l}\text { Children's } \\
\text { satisfaction towards } \\
\text { the classroom } \\
\text { learning on Chinese } \\
\text { character literacy }\end{array}$ & $\begin{array}{l}\text { C11:大家喜欢老师教新的字 } \\
\text { (We like to learn new Chinese } \\
\text { characters from the teacher) }\end{array}$ & & & $\sqrt{ }$ \\
\hline
\end{tabular}

During the self-administered process in answering the questions (items), the children would have to rate their approval to each statement according to the 'level of truth'. Then, they had to choose a response from five emoji images to indicate their approval. The emoji approval scale is shown in Figure 5. 
Shiat Lu WONG, Nyet Moi SIEW, Chiow Thai SOON. Development of a children questionnaire for measuring Chinese character literacy learning satisfaction

PROBLEMS

OF EDUCATION IN THE $21^{\text {st }}$ CENTURY Vol. 78 , No. 5, 2020

842

\section{Figure 5}

Emoji approval scale

\begin{tabular}{|c|c|c|c|c|}
\hline $\begin{array}{l}1 \\
><\end{array}$ & 2 & 3 & 4 & $\begin{array}{l}5 \\
20\end{array}$ \\
\hline $\begin{array}{l}\text { 完全不符合 } \\
\text { Strongly disagree } \\
\text { (This statement is } \\
\text { completely false!) }\end{array}$ & $\begin{array}{c}\text { 基本不符合 } \\
\text { Disagree } \\
\text { (No, I don't think it is } \\
\text { true.) }\end{array}$ & $\begin{array}{c}\text { 不确定 } \\
\text { No idea } \\
\text { (I don't know, maybe } \\
\text { it is somewhat true.) }\end{array}$ & $\begin{array}{c}\text { 基本符合 } \\
\text { Agree } \\
\text { (Yes, it is true.) }\end{array}$ & $\begin{array}{c}\text { 完全符合 } \\
\text { Strongly agree } \\
\text { (Yes, it is completely } \\
\text { true.) }\end{array}$ \\
\hline \multicolumn{2}{|c|}{ Negative response } & Neutral & \multicolumn{2}{|c|}{ Positive response } \\
\hline
\end{tabular}

Mun and Dreyer (1990) specified a small-scaled pilot test or a pioneer study can test the validity and reliability of a questionnaire. Thus, this research was preceded with a pioneer study. A highly validated questionnaire will help researchers in pinpointing more accurately about what the children gained from an intervention by surveying their learning satisfaction. A quality questionnaire relies on good items. Therefore, pre-testing on items is essential to warrant a quality questionnaire.

\section{Procedures}

A pre-test was executed to five children from the Year Two SJKC, which was essentially a cognitive test or an in-depth interview with the young children for testing the item quality. The purpose in pre-testing was to look at the item properties to determine 1) the range of the scale, if the children can choose their response options vary from low approval to high approval; 2) the readability of the items, if the language of the items is simple and straightforward to the children.

Five children were invited to sit in a circle to form a focus group for the pre-test. Goals and rules of the interview were explained carefully to the children during the introductory session. There was a short rehearsal before the real interview started. During the interview, the children were asked to read aloud the items (questions / statements) of the CCLLS questionnaire. This activity was to stimulate the children to 'think aloud' while reading aloud and it had been done at complete ease. If a child could not read or pronounce a character (word) correctly, this would signpost a comprehension problem, and would provide clues for the researcher to do further probing. During the question-answer process, the researcher tried to detect the language problems, and to discover the causes of the confusion and misinterpretation. The items were reformed and refined after the pre-test, then were to be submitted to the experts for content reviewing. The pre-test was followed by pilot tests. The researcher administered CCLLS questionnaire to 34 and 44 children respectively from two SJKC schools before collecting data from the true research.

\section{Administration of CCLLS Questionnaire}

Before the administration of CCLLS questionnaire, informed consent from the parents had been obtained. An intervention of Chinese character literacy learning was executed, and then it was completed with a literacy assessment. CCLLS questionnaire was used to measure the children's learning satisfaction. Guidelines on how to read a statement and to choose a proper response were explained in detail to the children. During the question-answer process, the children 'assessed' the intervention by doing self-evaluation on their experiences and feelings regarding the Chinese character literacy learning which was conducted within a timeframe of six weeks. Children's spontaneous recall is less than adults (De Leeuw, 2011), therefore the children were given ample time to complete the questionnaire. A set of five emoji images 
was used as the approval scale for each item. Despite there being no setting of time limit, the Vol. 78 , No. 5, 2020 children were able to complete twelve items within half an hour. The collected data was then analyzed by the researcher using the Winsteps Rasch software version 3.73.

\section{Rasch Analysis}

Rasch Measurement Model has been preferred over other methods since it is capable of measuring the functions of items and the ability of persons concurrently in a questionnaire. A Rasch analysis may take longer to process than a traditional analysis, but it provides a deeper understanding of instrument strengths and weaknesses (Boone \& Scantlebury, 2006). The application of the Rasch measurement can convert the raw data scores into data with similar intervals till it creates a linear, accurate and compact measurement scale. This is in line with the objective of this research which is to establish the reliability of the CCLLS questionnaire. It is imperative to ensure the precision of its items that are used in measuring the satisfaction dimension. Thus, using this model is an alternative and effective way to diagnose and analyze items within a questionnaire for its validity and reliability in an in-depth manner. The result of this analysis is an indicator for the validity and reliability of the CCLLS questionnaire.

Bond and Fox (2007) asserted that the Rasch modelling is an effective solution in preparing a highly valid and reliable instrument through the creation of in-depth statistics. An instrument is said to have a high validity and reliability when it can measure what it is supposed to measure (Creswell, 2005; Pallant, 2005). Wright and Mok (2004) stated that an objective measurement concept in the field of social and evaluation in education should consist of five criteria: 1) Gives off a linear measurement with similar intervals; 2) Makes a precise guess; 3) Identifies items that are misfits or outliers; 4) Overcomes the problem of missing data; 5) Creates a replicable measurement. Rasch measurement can fulfil these five criteria.

In other words, the measurement quality in evaluation and education using the Rasch model has the same measurement qualities as those used in the physics dimension like measuring length in meter and centimeter units, or kilogram measurements and so on. This is also proposed by Sumintono and Widhiarso (2015). The Rasch model is able to determine the validity and reliability of an instrument and ensure the item in the instrument is capable of contributing a consistent result with other groups.

\section{Data Analysis}

\section{Content Validity}

Validity refers to the accuracy of the measurement in an instrument. Content validity indicates the extent to which items adequately represent the content of the trait that the researcher wishes to measure (Creswell, 2005). Subject matter expert review is always a good step to assess content validity for an instrument development. Kline (2005) stated that an expert's review is necessary to ensure the accuracy of a construct as well as the clarity of its content. Mullen (2003) remarked that a group of experts are those who are trained in a specific field. To follow these principles, the researcher had sent the CCLLS questionnaire to five experts who have vast knowledge in the field of education for content validation. The experts exhibit these three characteristics:

(1) A person who works in the field and has a profession of more than five years;

(2) A person who possesses a specific experience;

(3) An individual who is directly involved in the related study. 
Shiat Lu WONG, Nyet Moi SIEW, Chiow Thai SOON. Development of a children questionnaire for measuring Chinese character literacy learning satisfaction

PROBLEMS

OF EDUCATION

IN THE $21^{\text {st }}$ CENTURY

Vol. 78, No. 5, 2020

In tandem, the researcher had referred to a group of lecturers from the Chinese Studies Unit in an Institute of Teacher Education (IPG), the Chief of Chinese Language Panel from a school, and a reviewer from the Education Faculty of a university who is an expert in measurement and assessment. Besides the aforementioned reviewers, an expert in psychology and counselling from Kota Kinabalu District Education Department (PPD) had also been consulted to validate the CCLLS questionnaire items. All the comments and advice from the experts were considered to refine the items, and to improve the meaning, language and presentation of the questionnaire. Table 2 showcases the overall comments of the experts.

Table 2

Comments from the panel of experts on CCLLS questionnaire

\begin{tabular}{llll}
\hline Reviewer & Position & Expertise & Comment \\
\hline Expert A & $\begin{array}{l}\text { Senior Lecturer, } \\
\text { Chinese Studies Unit } \\
\text { in IPG }\end{array}$ & Linguistics & $\begin{array}{l}\text { Emphasized to use the easiest form of language in } \\
\text { the questionnaire that is suitable for respondents } \\
\text { aged between 7-8 years old. }\end{array}$ \\
Expert B & $\begin{array}{l}\text { Head of the } \\
\text { Department, Education } \\
\text { Faculty }\end{array}$ & $\begin{array}{l}\text { Measurement and } \\
\text { Assessment }\end{array}$ & $\begin{array}{l}\text { Proposed to add the 'neutral' perception in the 5-point } \\
\text { Likert scale as an intermediate option in CCLLS } \\
\text { questionnaire. }\end{array}$ \\
\hline $\begin{array}{l}\text { Expert C } \\
\text { Head of the Counseling }\end{array}$ & $\begin{array}{l}\text { Psychology and } \\
\text { Department, PPD }\end{array}$ & $\begin{array}{l}\text { Suggested to modify the description of the scale } \\
\text { response from "level of approval' to "level of truth". }\end{array}$ \\
\hline
\end{tabular}

The researcher used the data of the evaluation from the reviewers to generate Content Validity Index (CVI). Content Validity Index or CVI, which is comprised of the item-CVI (i-CVI), and the specialist-CVI (s-CVI) was modified from Kappa's (K*) statistics (Lyman, 1986). Pilot et al. (2007) posited that the acceptable value of $i-C V I$ is higher than .78. Davies (1971), Grant and Davis (1997), as well as Pilot et al. (2007) suggested that the acceptable s-CVI value is higher than 0.80 . The result from the calculation showed both the CVI values (item and specialist) were .97 (97\% approval level). This reflects the CCLLS questionnaire had a high content validity as shown in Table 3.

Table 3

Content validity index of the CCLLS questionnaire

\begin{tabular}{lc}
\hline Content Validity Index (CVI) & Index Value \\
\hline Based on specialist (s-CVI > .80) & .97 \\
Based on item (i-CVI > .78) & .97 \\
Interpretation & Very High \\
\hline
\end{tabular}


Shiat Lu WONG, Nyet Moi SIEW, Chiow Thai SOON. Development of a children questionnaire for measuring Chinese character literacy learning satisfaction

\section{Construct Validity}

The Rasch model can provide researchers many techniques and in-depth analysis to examine the validity and reliability of the constructs in CCLLS questionnaire. A basic Rasch analysis is a method to use for this purpose by applying five statistical tests on:

(1) Item polarity measured with Point Measure Correlation

(2) Item fit measured with mean square

(3) Confirmation of dimensionality

(4) Cronbach's coefficient alpha (KR-20)

(5) Item reliability and person reliability with their separation indices, respectively

An inspection for the Point Measure Correlation (PTMEA-CORR) was conducted to identify the polarity of the items. The fit statistics were examined through the infit and outfit value of Mean Square (MNSQ). According to Bond and Fox (2007), the MNSQ should be within the range of 0.6-1.4 to ensure the item is fit or suitable to measure the construct. In addition, Sumintono and Widhiarso (2015) asserted that a good MNSQ value is within 0.5-1.5. In the context of this study, the researcher referred to the benchmarks proposed by Boone et al. (2014), which has the same MNSQ range suggested by Sumintono and Widhiarso (2015).

In addition, range guide from the analysis of unidimensionality using the Rasch model reveals fit statistics more easily compared to using other measurement models (Tennant \& Pallant, 2006; Sick, 2011; Wright, 1999). This was also asserted by Jusoh, et al. (2014). Principal Component Analysis of Rasch Residual (PCAR) would provide pertinent data in examining the item construct. An item that fits with the Rasch measurement would demonstrate an evidence of sufficient unidimensionality (Wright, 1999; Sick, 2011). As a rule of thumb, Reckase (1979) opined that unidimensionality is grounded on the requirements of 1) Raw variance explained by measures, 2) Unexplained variance in the first contrast, and 3) Eigenvalue. Raw variance explained by measures should be greater than $20 \% .40 \%$ is a good indicator of unidimensionality. Sumintono and Widhiarso (2015) asserted that unexplained variance in the first contrast should be lower than 15\%. Eigenvalue should be less than 5 (Linacre, 2005).

\section{Reliability}

Reliability refers to the degree to which an instrument yields a consistent result. Rasch analysis can provide similar psychometric information to traditional analyses for the reliability of an instrument (Boone \& Scantlebury, 2006). The value of an item reliability and a person reliability provides a statistic similar to the commonly used KR-20 reliability test. Besides the value of Cronbach Alpha (KR-20), the separation index is also measured in Rasch analysis. Bond and Fox (2007) asserted that a high value of the reliability (KR-20) is between .71 .99 which is within the best value $(71 \%$ - 99\%). Item reliability also verifies an instrument's construct validity. Separation is the distribution of position for the person and item along the variable (Chan, et al., 2014). A good separation index is more than 2.0 (Linacre, 2010). In this research, the researcher determined the reliability of the CCLLS questionnaire proposed by Sumintono and Widhiarso (2015) as shown in Table 4. 
Shiat Lu WONG, Nyet Moi SIEW, Chiow Thai SOON. Development of a children questionnaire for measuring Chinese character literacy learning satisfaction

OF EDUCATION IN THE $21^{\text {st }}$ CENTURY Vol. 78 , No. 5, 2020

Table 4

Reliability statistics

\begin{tabular}{lll}
\hline Statistics & Index & Interpretation \\
\hline & & Low \\
& $<.50$ & Moderate \\
Cronbach Alpha (KR-20) & $.50-.60$ & Good \\
& $.60-.70$ & High \\
& $.70-.80$ & Very high \\
\hline & $>.80$ & \\
\hline Item and person reliability & $<.67$ & Low \\
& $.67-.80$ & Satisfactory \\
& $.81-.90$ & Good \\
& $.91-.94$ & Very good \\
\end{tabular}

Source: Sumintono and Widhiarso (2015)

\section{Research Results}

\section{Item Statistics}

According to Boone, at el. (2014), the criteria below used as benchmarks for determining the fit statistics in the Rasch measurement.

(1) The accepted value of outfit Mean Square (MNSQ): $0.5<\mathrm{MNSQ}<1.5$

(2) The accepted value of outfit Z-Standardized (ZSTD): $-2.0<$ ZSTD $<+2.0$

(3) The accepted value of Point Measure Correlation (PTMEA-CORR): $0.4<$ PTMEA-CORR $<0.85$

Further investigation needed to be done for an item if it was detected outside any one of the benchmarks set by Boone, et al. (2014). According to Simintono and Widhiarso (2015), any item that fulfils one of the benchmarks can be retained. The findings of the item statistics which include item polarity and item fit are shown in Table 5.

\section{Table 5}

Item statistics

\begin{tabular}{llllll}
\hline \multirow{2}{*}{ Item } & PTMEA-CORR & \multicolumn{2}{l}{ Infit } & & \multicolumn{2}{l}{ Outfit } \\
\cline { 3 - 6 } & & MNSQ & ZSTD & MNSQ & ZSTD \\
\hline C10 & .49 & 1.25 & 2.3 & 1.15 & 1.4 \\
B7 & .51 & 1.22 & 2.2 & 1.24 & 2.4 \\
B8 & .53 & 1.15 & 1.6 & 1.14 & 1.5 \\
B6 & .47 & 1.15 & 1.4 & 1.07 & .7 \\
C12 & .48 & 1.09 & .9 & 1.02 & .2 \\
A4 & .55 & .99 & -.1 & .96 & -.4 \\
B9 & .60 & .95 & -.5 & .88 & -1.2 \\
A1 & .50 & .92 & -.8 & .89 & -1.0 \\
B5 & .54 & .88 & -1.3 & .88 & -1.2 \\
A3 & .57 & .88 & -1.2 & .85 & -1.5 \\
C11 & .55 & .83 & -1.6 & .76 & -2.3 \\
A2 & .50 & .78 & -2.5 & .80 & -2.2 \\
\hline
\end{tabular}


Shiat Lu WONG, Nyet Moi SIEW, Chiow Thai SOON. Development of a children questionnaire for measuring Chinese character literacy learning satisfaction

$\mid$\begin{tabular}{l} 
PROBLEMS \\
OF EDUCATION \\
IN THE 21 $1^{\text {st }}$ CENTURY \\
Vol. 78, No. 5, 2020 \\
\hline 847
\end{tabular}

From Table 5, all the items are positive PTMEA-CORR ranging from .47 to .60 . The positive value indicated the items can measure the constructs that are supposed to be measured (Bond \& Fox, 2007; Linacre, 2010). This result showed all the items were within the accepted point measure correlation range from .40 to .85 . The polarity statistics indicated the items in the CCLLS questionnaire can measure the constructs as remarked by Bond and Fox.

According to Bond and Fox (2007), the outlier-sensitive statistics (outfit statistics) reveals large difference between observed and expected value of an item which is far from the person's ability, whereas the information-weighted fit statistics (infit statistics) highlights the residual of an item that is close to the person's ability. According to Mohd Jailani (2011), the outfit statistics of mean square (MNSQ) provides more pronounced measurement compared to the infit statistics in Rasch analysis. Besides the infit and outfit MNSQ values, the infit and outfit of Z-Standardized (ZTSD) should be within the range of -2 to +2 . However, the ZSTD value can be ignored if the MNSQ value has fulfilled the conditions of item suitability and sample adequacy (Bond \& Fox, 2007; Linacre, 2010).

Table 5 showed the MNSQ of the items range from .78 to 1.25 (infit), and .76 to 1.24 (outfit). All the items were within the prescribed infit and outfit MNSQ value which is .501.50. Meanwhile, the infit and outfit of ZSTD values were slightly out of the acceptable range $(-2$ to +2$)$. However, the ZSTD value could be ignored due to the contentment in MNSQ and PTMEA (Bond \& Fox, 2007; Linacre, 2010). Conclusively, the items could consistently measure the constructs in CCLLS questionnaire.

\section{Confirmation of Dimensionality}

Unidimensionality is a fundamental requirement for a Rasch model and it is frequently detected by using Principal Component Analysis of Rasch Residual (PCAR). The concept of unidimensionality is usually defined as a single latent trait being able to account for the performance on items forming a questionnaire (Brentari \& Golia, 2007). The principal components analysis of the CCLLS questionnaire is presented in Table 6.

\section{Table 6}

\section{Principal components analysis}

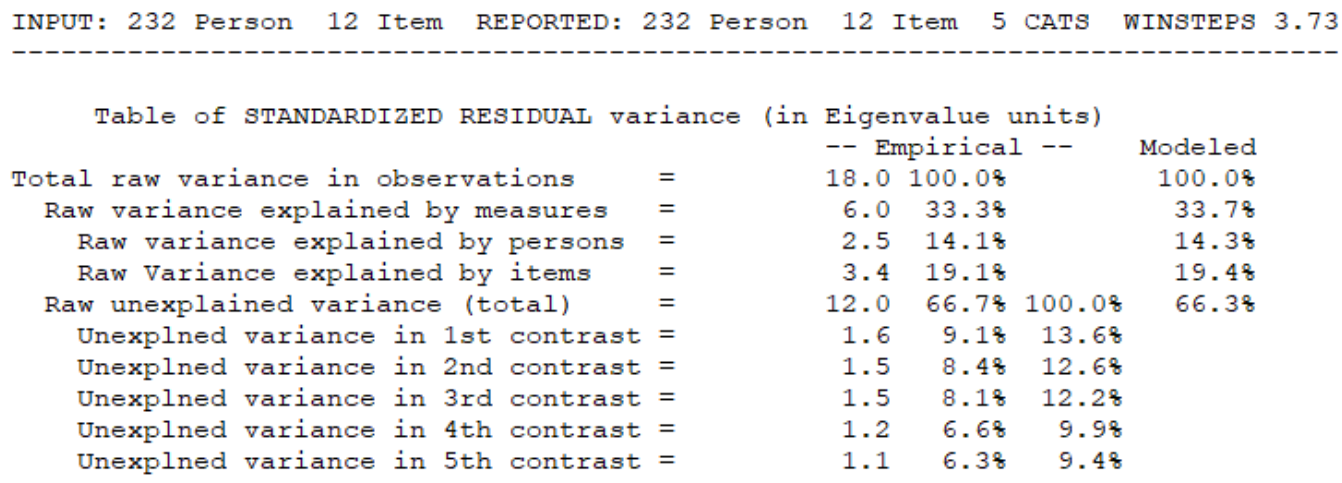

Based on the result in Table 6, the observed value of the Raw Variance Explained by Measures is $33.3 \%$ which fulfilled the minimum criteria of $20 \%$ stated by Sumintono and Widhiarso (2015). Anyway, it is not good enough to be considered as unidimensional. Thus, the second requirement for unidimensionality was examined. The value of $9.1 \%$ was detected from Unexplained Variance in 1st Contrast, which is less than 15\%. As confirmation, the unexplained variances from $1^{\text {st }}$ contrast to $5^{\text {th }}$ contrast were detected; they are all less than $10 \%$. 
Shiat Lu WONG, Nyet Moi SIEW, Chiow Thai SOON. Development of a children questionnaire for measuring Chinese character literacy learning satisfaction

PROBLEMS

OF EDUCATION IN THE $21^{\text {st }}$ CENTURY Vol. 78, No. 5, 2020

The third prerequisite is the eigenvalue of the $1^{\text {st }}$ contrast of unexplained variance should be less than 5 (Linacre, 2005). From the result, the eigenvalue shown is 1.6, which is less than 2 , indicates the second construct does not clearly exist (Linacre, 2005). As a result, there is a single construct, which is satisfaction of Chinese character literacy learning could be measured by CCLLS questionnaire.

\section{Reliability and Separation Indices}

In relevance to the reliability of this research, the person-measure reliability indicates how well the 8-year-old children can be distinguished based on their responses. The item-measure reliability specifies how well the items (statements) can be discriminated from one another based on their authenticity approved by the children. Table 7 showed the CCLLS reliability based on the Cronbach's coefficient alpha (KR-20), which is .81. This value infers that the reliability of the CCLLS questionnaire is within a very high range (Sumintono \& Widhiarso, 2015). The item reliability and person reliability with their respective separation indices are presented in Table 7.

Table 7

Result of the Reliability Test

\begin{tabular}{llll}
\hline Cronbach Alpha (KR-20) & Reliability & Separation \\
\hline & .81 & & \\
Item & & .91 & 3.23 \\
Person & .77 & 1.81 \\
\hline
\end{tabular}

Referring to Table 7 , the item reliability is 0.91 , which is within very good range (Bond \& Fox, 2007; Sumintono \& Widhiarso, 2015; Linacre, 2010). The item separation index was 3.23, which is more than 2.0, indicating CCLLS has a good spread of items (Linacre, 2010) that it could distinguish the children according to the level of satisfaction. According to Ardiyanti (2016), the number of separate item strata $(H)$ can be obtained from the separation index by calculating the equation: $H=[(4 \mathrm{x}$ separation index $)+1] / 3$. The result from the calculation in this study is $H=4.64$. (can be rounded up to 5). This value supposed that the items of CCLLS questionnaire can be categorized into five levels based on the children's learning satisfaction (very low, low, moderate, high, and very high), agreeing the five response categories in CCLLS questionnaire.

The person reliability of .77 is in satisfactory range, meanwhile the person separation of CCLLS is 1.81. The item separation more than 1.00 indicates there is enough spread of item (Bond \& Fox, 2007). Abd Rahman and Siew (2019) stated the separation value greater than 1.4 can be considered as moderately good. Separation index of 1.81 produces strata, $H=2.75$ (can be rounded up to 3 ). This value indicates the children could be divided into three groups according to their response type (positive, neutral and negative) based on the items in CCLLS questionnaire. The overall of the reliability findings is presented in Table 8.

Table 8

Summary of the reliability findings

\begin{tabular}{llll}
\hline & $\begin{array}{l}\text { Rasch } \\
\text { Measurement }\end{array}$ & $\begin{array}{l}\text { CCLLS } \\
\text { Questionnaire }\end{array}$ & Interpretation \\
\hline Cronbach Alpha (KR-20) & $>.80$ & .81 & Very high \\
Item Reliability & $.91-.94$ & .91 & Very good \\
Item Separation Index & $>2.0$ & 3.23 & Good \\
Person Reliability & $.67-.80$ & .77 & Satisfactory \\
Person Separation Index & $>1.4$ & 1.81 & Moderately Good \\
\hline
\end{tabular}


Shiat Lu WONG, Nyet Moi SIEW, Chiow Thai SOON. Development of a children questionnaire for measuring Chinese character literacy learning satisfaction

PROBLEMS

OF EDUCATION

IN THE $21^{\text {st }}$ CENTURY

In order to gain insight into the problems that encountered the slightly low person

Vol. 78, No. 5, 2020

reliability of CCLLS questionnaire, the researcher had made further study by using Wright map as shown in Figure 6.

\section{Figure 6}

Wright map

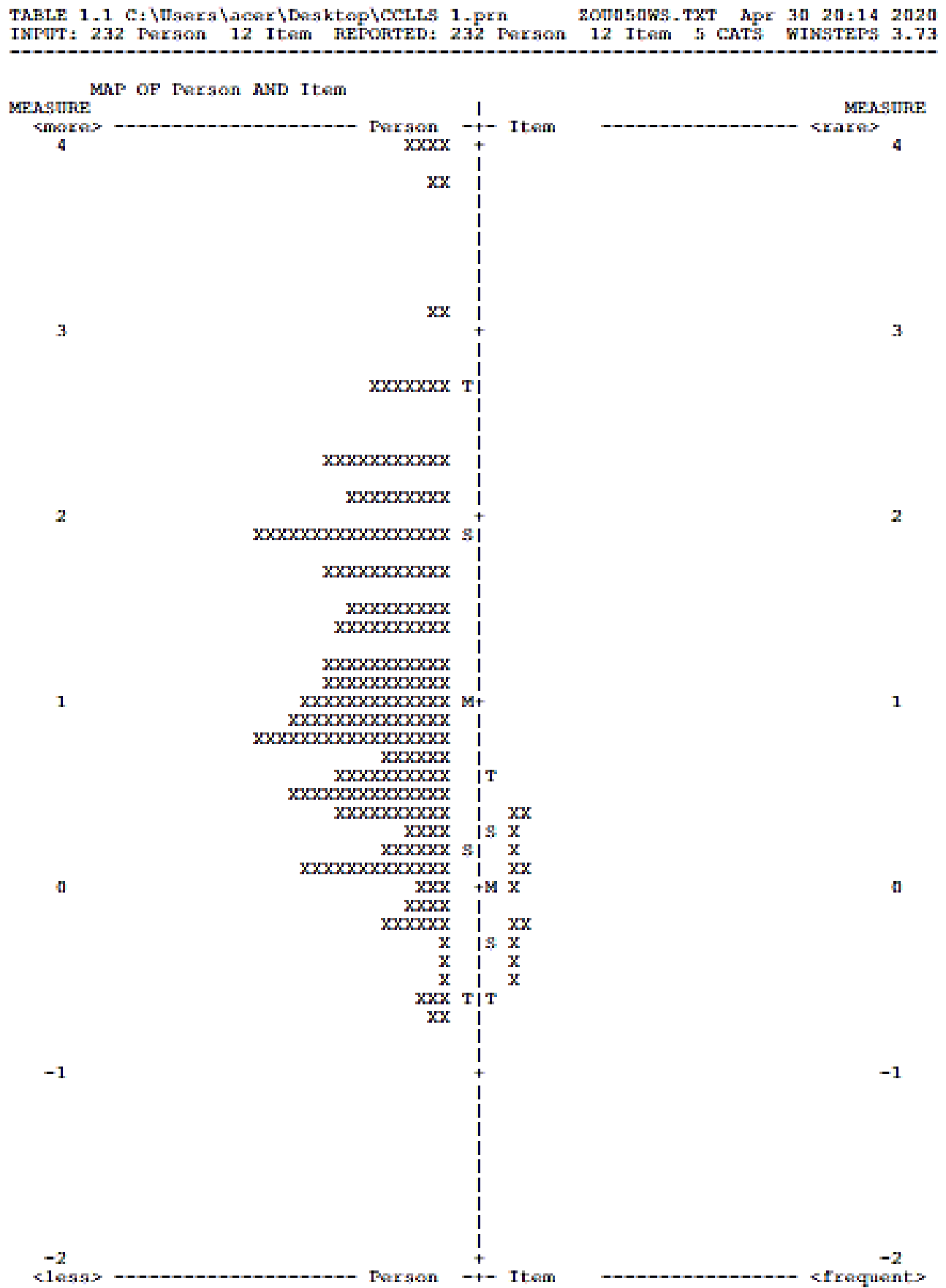


Shiat Lu WONG, Nyet Moi SIEW, Chiow Thai SOON. Development of a children questionnaire for measuring Chinese character literacy learning satisfaction

PROBLEMS

OF EDUCATION IN THE $21^{\text {st }}$ CENTURY Vol. 78, No. 5, 2020

850

The map of persons and items had been examined by comparing the range and position of the item-measure distribution to the range and position of the person-measure distribution. Figure 6 demonstrates the person-measure, which has normal distribution spreading along the ruler (center vertical dotted line), and it is well centred. There is a noticeable distance between the person-measure mean ('M' at the left side), and item-measure mean ('M' at the right side).

\section{Discussion}

The research was accomplished with the findings and summary which were presented in Table 5 and Table 8. Based on the aforementioned findings, it was proposed that CCLLS questionnaire could perform statistical confidence in validity and reliability for measuring Chinese character literacy learning satisfaction among Year Two primary school students. Surveying learning satisfaction by using CCLLS questionnaire could be feasible to 8-year-old children in SJKC.

In the Rasch model, there is always an assumption stated that a person's reliability is influenced by an item's attribute, and vice versa (Linacre, 1994). The map in Figure 6 indicates that the children's responses are distributed from strongly agree to strongly disagree, as it would be expected from the children's perception on Chinese character literacy learning. In fact, there should be some items located at each point of the scale, and the items should be distributed to all areas on the ruler if they are to measure the learning satisfaction of all children. However, the persons were not able to cover all the items in the form of adequate responses. It is remarkable in Figure 6, the mean of the person-measure $(1.11$ logit) locates higher than the mean of the item-measure (0.00 logit). There are two explanations that can be proposed to this consequence:

(1) Insufficient item to cover the children's high-rate response at the centre area (close to the pass point) of the person distribution.

(2) The children's rating in CCLLS learning satisfaction was too high. It might be true if the children were actually very satisfied with the outcome of the literacy learning after participating in the intervention.

Another possibility of overrating was due to some children's comprehension problems and poor literacy on the items. A significant study conducted by Hakstian and Whalen (1976) showed that children who scored low on the reading comprehension had a significantly lower data quality on the psychometric reliability. De Leeuw (2011) emphasized that children aged 7 to 10 are afraid of doing something wrong. Hence, it would result in a tendency for them to choose a positive response at most of the time, just to please their teachers (Borgers et al., 2000; De Leeuw, 2011). The interaction effects between respondent characteristics and item characteristics can affect the data quality of a questionnaire (Borgers \& Hox, 2001), and it could always happen especially in the children's questionnaire. The outcome of the research made an implication that the children characteristics and their cognitive growth would have some influence on the data quality of the questionnaire. The researcher also noted that in fact most children did not have any difficulty in choosing any response, and considered to add extra items such as "I find reading Chinese storybooks challenging", and "I think Chinese word puzzle game is too difficult" to increase the number and variety of the items. However, making response to negation (negative formulated statement) is a cognitive challenge for children (Borgers et al., 2000; De Leeuw, 2011), thus the researcher is rather hesitant to do the modification. Nevertheless, there is always a space for improvement. While thinking to enhance the quality of the questionnaire, CCLLS had already performed the construct validity and reliability based on Rasch analysis in this research.

A study in developing a learning satisfaction questionnaire for 10 to 12 years old 
primary school children was conducted by Hu (2010) in Changsha, China. Hu's research consisted of 901 participants. The questionnaire was validated through factorial analysis (KMO and Barlett's Test of Sphericity) and went through two pilot studies with three times of item modifications. After exempting the missing data, the reliability test of 863 participants showed .889 in Cronbach's coefficient, which was considered very high. The result of the reliability test implied that the $10-12$ years old children in China performed better in understanding the items of a questionnaire in their native language, if compared with most of the $7-8$ years old children in CCLLS survey, who might probably have more difficulties to understand the items in a second language. Moreover, $10-12$ years old children might have better cognitive function than $7-8$ years old children (De Leeuw, 2011).

The questionnaire in Hu's research consisted of 46 items which was developed through six dimensions: 1) Learning environment; 2) Teaching and facilitating; 3) Relationship with teachers; 4) Relationship with classmates; 5) Family relationship; 6) Academic performance. According to $\mathrm{Hu}$ (2010), the mean scores of the dimension in "Teaching and facilitating" and "Relationship with teachers" were the highest among the six satisfaction dimensions in the survey. This result indicated the $10-12$ years old children could be having a tendency to please their teachers during the administration of the questionnaire (Hu, 2010). Compared to CCLLS, this 4-point Likert scale questionnaire measured a broader scope and a wider perspective on students' learning satisfaction. However, the outcome from the evaluation of each dimension seemed to be more informative and useful, compared to the evaluation of all dimensions as an overall outcome (Hu, 2010). Hu's statement infers that a questionnaire on learning satisfaction with a smaller scope and fewer dimensions (CCLLS is an example) could be more helpful, practical and precise in assisting an educator to detect the students' learning problems.

Learning satisfaction in general has been well-researched but learning satisfaction in Chinese character literacy is rare. CCLLS was developed to evaluate the outcome of the learning satisfaction in Chinese character literacy. It has been developed conveniently, and specifically to measure the students' learning satisfaction is relevant to an intervention. Therefore, using CCLLS as 'one size fits all' is not advisable. More studies should be done to extend CCLLS application in surveying the learning satisfaction for other subjects.

\section{Conclusions and Implications}

Learning is an important part of childhood. Enhancing the learning and teaching quality may result in the satisfaction of children's learning. For young children, learning satisfaction is equivalent to happiness that will make their life shine with hope. In most of the countries, children are no longer an ignored minority in authorized statistics. When proxy-reporting from parents or guardians is no longer considered good enough, educators should hear the voice from the children itself.

This research was concerning children's learning satisfaction, and the regarding information was directly collected from the children. Students are the main part of education and learning. Motivation should be given to young children by creating more chances for them to voice out what they think or feel in a more manageable and easier way, such as responding through a questionnaire. Hence, the main objective of developing a children questionnaire is for learning and is a part of learning.

This research put its focus on the children by studying and analysing the factors that influence their learning experience. Measuring knowledge, skills and attitudes among young children is a major methodological challenge in this research. Methodological studies on adult populations have shown that even adults may experience problems with certain questions characteristics in a survey. Thus, with children respondents, an error in a question such as ambiguity and negations will give a larger impact and will be more difficult to compensate.

\begin{tabular}{|l} 
PROBLEMS \\
OF EDUCATION \\
IN THE 21 $1^{\text {st }}$ CENTURY \\
Vol. 78, No. 5, 2020 \\
\hline 851
\end{tabular} 
Shiat Lu WONG, Nyet Moi SIEW, Chiow Thai SOON. Development of a children questionnaire for measuring Chinese character literacy learning satisfaction

PROBLEMS

OF EDUCATION IN THE $21^{\text {st }}$ CENTURY Vol. 78 , No. 5, 2020

852

These problems had been magnified and clarified in the early stage of CCLLS questionnaire item formulation.

Rasch model was used to examine the construct validity and reliability of CCLLS questionnaire. The meticulous analysis of Rasch measurement had shown the suitability of the items in measuring the learning satisfaction of Chinese character literacy. The outcome of a tailored study can be more easily estimated by using a valid and reliable tool. However, developing and administering quality questionnaires for children requires a careful judgment process. The length of the questionnaire, question wording and structure are some of the issues that would determine the data quality. Consequently, the role of a child might be transposed as an 'evaluator' to determine the quality of the questionnaire. The age of 8 is a major growing point in the cognitive and social development. Development of CCLLS is the integration of theoretical and empirical knowledge on children characteristics. The results of the research indicated that CCLLS questionnaire could be feasible and suitable in measuring Chinese Character Literacy Learning Satisfaction (CCLLS) based on the perception of 8-year-old students in the primary schools of SJKC. The findings may also assist educators to re-evaluate the learning outcomes of Chinese character literacy to enhance the effectiveness of learning and teaching Chinese subject in other countries.

As by-purpose, the development of CCLLS questionnaire had also initiated a good start for the 8-year-old SJKC children in learning how to do self-evaluation by answering a questionnaire and this skill would be further explored in future studies. Moreover, since this research was only conducted in Chinese national type schools (SJKC), extension of the research to other national schools that offer Chinese language as learning subject is recommended. Hence for achieving educational equity, comparison of the learning satisfaction can be done among the students of the main-stream national schools and the Chinese national type schools.

\section{Acknowledgements}

The authors would like to express their deepest appreciation to Mr. Lui Lep Ming who is the former National Core Instructor of Malaysian Primary School Standardized Curriculum (KSSR), and Dr. Chiam Sun May from Kent Institute of Teacher Education for their generous knowledge sharing, support and inspiration.

\section{References}

Abd Rahman, M. S., \& Siew, N. M. (2019). Kesahan dan kebolehpercayaan ujian pemikiran masa hadapan untuk pelajar tingkatan empat menggunakan model pengukuran Rasch [Validity and reliability of a future thinking test for tenth graders using the Rasch measurement model]. Jurnal Penyelidikan Pendidikan Guru [Journal of Research in Teacher Education], 14, 93-110.

Alhabshi, S. O., \& Hakim, H. (2001, September 1-2). Dasar dan perlaksanaan sistem pendidikan kebangsaan [Policy and implementation of the national education system] [Congress session]. Malay Education Congress. PWTC, Kuala Lumpur. http://www.teo-education.com/teophotos/ albums/userpics/131_Dasar_dan\%20Pelaksanaan_Sistem\%20Pendidikan\%20Kebangsaan.pdf

Amaoto, P., \& Ochiltree, G. (1987). Interviewing children about their family. A note on data quality. Journal of Marriage and Family, 49(3), 669-675. https://doi.org/10.2307/352212

Anderson, E. W., Fornell, C., \& Lehmann, D. R. (1994). Customer satisfaction, market share, and profitability: Finding from Sweden. Journal of Marketing, 58(3), 53-66. https://doi.org/10.2307/1252310

Anderson, J. R. (1996). ACT: A simple theory of complex cognition. American Psychologist, 51(4), 355368. https://doi.org/10.1037/0003-066X.51.4.355

Ardiyanti, D. (2016). Aplikasi model Rasch pada pengembangan skala efikasi diri dalam pengambilan keputusan karier siswa [Application of Rasch's model of measurement for the self-efficacy scale in undergraduate's career decision making], Jurnal Psikologi [Psychological Journal], 43(3), 248263. https://doi.org/10.22146/jpsi.17801 
Shiat Lu WONG, Nyet Moi SIEW, Chiow Thai SOON. Development of a children questionnaire for measuring Chinese character literacy learning satisfaction

PROBLEMS

OF EDUCATION

IN THE $21^{\text {st }}$ CENTURY

Vol. 78 , No. 5, 2020

853

Bond, T. G., \& Fox, C. M. (2007). Applying the Rasch model: Fundamental measurement in the human sciences $\left(2^{\text {nd }}\right.$ ed.). Lawrence Erlbaum Associates. https://psycnet.apa.org/record/2007-07586-000

Boone, W. J., \& Scantlebury, K. (2006). The role of Rasch analysis when conducting science education research utilizing multiple-choice tests. Science Education, 90(2), 253-269. https://doi.org/10.1002/sce.20106

Boone, W. J., Staver, J. R., \& Yale, M. S. (2014). Rasch analysis in the human sciences. Springer. https://doi.org/10.1007/978-94-007-6857-4

Borgers, N., de Leeuw, E., \& Hox, J. (2000). Children as respondents in survey research: Cognitive development and research quality. Bulletin of Sociological Methodology, 66, 60-75. https://doi.org/10.1177/075910630006600106

Borgers, N., \& Hox, J. (2001). Item non-response in questionnaires with children. Journal of Official Statistics, 17(2), 321-335.

Brentari, E., \& Golia, S. (2007). Unidimensionality in the Rasch model: How to detect and interpret. Statistica, 67(3), 253-261. https://doi.org/10.6092/issn.1973-2201/3508

Chan, S. W., Ismail, Z., \& Sumintono, B. (2014). A Rasch model analysis on secondary students' statistical reasoning ability in descriptive statistics. Procedia Social and Behavioral Sciences, 129 (2014), 133-139. https://doi.org/10.1016/j.sbspro.2014.03.658

Che Nidzam, C. A., Osman, K., \& Lilia, H. (2010). Hubungan ramalan persekitaran pembelajaran makmal sains dengan tahap kepuasan pelajar [The relationship between environment prediction and laboratory scientific learning with student's satisfaction level]. Jurnal Pendidikan Malaysia [Malaysian Education Journal], 35(2), 19-30.

Creswell, J. W. (2005). Educational research: Planning, conducting and evaluating quantitative and qualitative research. Prentice Hall.

Curriculum Development Division. (2016). Dokumen standard kurikulum dan pentaksiran, sekolah jenis kebangsaan Cina tahun dua edisi pertama [Standard curriculum and assessment document of Chinese language in primary two Chinese national type schools $\left.\left(1^{\text {st }} \mathrm{ed}.\right)\right]$. Ministry of Malaysian Education.

Davies, I. I. C. (1971). The management of learning. C. Gain Hill.

De Leeuw, E. (2011). Improving data quality when surveying children and adolescents: Cognitive and social development and its role in questionnaire construction and pretesting. Naantali Finland.

Dong, B. F., (2006). 语文教育心理学 [Educational psychology in Chinese Teaching] (1" ed.). Shanghai Educational.

Fitts, P. M., \& Posner, M. T. (1967). Human performance. Brooks/Cole.

Grant, J., \& Davis, L. (1997). Selection and use of content experts for instrument development. Research in Nursing \& Health, 20(3), 269-274. https://doi.org/10.1002/(SICI)1098240X(199706)20:3<269::AID-NUR9>3.0.CO;2-G

Guolla, M. (1999). Assessing the teaching quality to student satisfaction relationship: Applied customer satisfaction research in the classroom. Journal of Marketing Theory and Practice, 7(3), 87-97. https://doi.org/10.1080/10696679.1999.11501843

Hakstian, A. R., \& Whalen, T. E. (1976). A K-sample significance test for independent alpha coefficients. Psychometrika, 41, 219-231. https://doi.org/10.1007/BF02291840

Hamed, S., Bahari, P., \& Abdullah, A. G. K. (2008). Korelasi antara persekitaran pembelajaran matematik, sikap pelajar terhadap matematik dan pencapaian pelajar dalam matematik: satu kajian kes [The correlation between learning environment of mathematics and mathematics achievement of student: A case study]. Esteem Academic Journal, 4(2), 91103. http://ir.uitm.edu.my/id/eprint/4031

Hu, X., (2010). 小学生满意度调查编制表的初步编制 [The Development of the learning satisfaction questionnaire for primary school students]. Normal University of Hunan. https://xueshu.baidu. $\mathrm{com} /$ usercenter/paper/show?paperid $=1 \mathrm{cfecf} 2 \mathrm{fbee} 5 \mathrm{ba} 5 \mathrm{a} 6 \mathrm{efb} 317130 \mathrm{~b} 615 \mathrm{a} 6 \&$ site $=\mathrm{xueshu}$ _se

Jusoh, M. S., Amlus, M. H., Osman, A., \& Abidin, R. (2014). Development and validation of a multidimensional measure: Manufacturing practices, knowledge transfer and manufacturing capabilities in Malaysian Manufacturing Companies. Australian Journal of Basic and Applied Sciences, 8(12), 25-29. 
Shiat Lu WONG, Nyet Moi SIEW, Chiow Thai SOON. Development of a children questionnaire for measuring Chinese character literacy learning satisfaction

PROBLEMS

OF EDUCATION IN THE $21^{\text {st }}$ CENTURY Vol. 78, No. 5, 2020

Kenny, D. (1985). The effect of repetition on the academic performance of primary school repeaters. Australasian Journal of Special Education, 9(2), 16-23. https://doi.org/10.1017/S1030011200021382

Kim, H.-B., Fisher, D. I., \& Fraser, B. J. (2000). Classroom environment and teacher interpersonal behaviour in secondary science classes in Korea. Evaluation and Research Education, 14(1), 3-22. https://doi.org/10.1080/09500790008666958

Kline, T. (2005). Psychological testing: A practical approach to design \& evaluation. Sage. https://dx.doi. org/10.4135/9781483385693

Lewis, J. R. (1995). IBM computer usability satisfaction questionnaires: Psychometric evaluation and instructions for use. International Journal of Human-Computer Interaction, 7(1), 57-78. https://doi.org/10.1080/10447319509526110

Li, X. L. (2019, JANUARY). 春风化雨谈“写字”——浅析现代认知心理学与小学写字教学 [Brief analysis on the teaching and learning of Chinese characters from a cognitive psychological perspective]. 语文课堂 [Language Classroom], 33-34. http://www.jiaoshizzs.com/news/81.html

Linacre, J. M. (1994). Constructing measurement with many-facet Rasch model. In M. Wilson (Ed.), Objective measurement: Theory into practice (Vol. 2, pp. 129-144). Ablex.

Linacre, J. M. (2005). Standard errors: Means, measures, origins and anchor values. Rasch Measurement Transactions, 19(3), 1030.

Linacre, J. M. (2010). A user's guide to FACETS Rasch-model computer programs. Program manual 3.67.0. [Software manual]. Winsteps.com.

Lyman, H. B. (1986). Test scores and what they mean (4 ${ }^{\text {th }}$ Eds). Prentice Hall Englewood Cliffs.

Mohd Jailani, M. K. (2011). Introductory manual on Rasch's measurement \& Winstep. Faculty of Education, University Kebangsaan Malaysia.

Mullen, P. M. (2003). Delphi: Myths and reality. Journal of Health Organization and Management, 17(1).37-52. https://doi.org/10.1108/14777260310469319

Mun, P., \& Drever, E. (1990). Using questionnaires in small-scale research. A teacher's guide. The Scottish Council for Research in Education.

National Curriculum (1997). Standard Chinese primary school curriculum: Chinese national type school, Ministry of Education Malaysia.

Pallant, J. (2005). SPSS survival manual - A step by step guide to data analysis using SPSS for Windows (Version 12). Allen and Unwin.

Pilot, D., Beck, C., \& Owen, S. (2007). Is the CVI an acceptable indicator of content validity. Research in Nursing \& Health, 30(67), 459. https://doi.org/10.1002/nur.20199

Reckase, M. D. (1979). Unifactor latent trait models applied to multifactor tests: Results and implications. Journal of Educational Statistics, 4(3), 207-230. https://doi.org/10.2307/1164671

Sick, J. (2011). Rasch measurement and factor analysis. Testing \& Evaluation SIG Newsletter, 15(1), 15-17. http://jalt.org/test/PDF/Sick6.pdf

Simpson, E. J. (1972). The classification of educational objectives in the psychomotor domain. Gryphon House.

Sumintono, B., \& Widhiarso, W. (2015). Aplikasi pemodelan Rasch pada assesment pendidikan [Rasch model application on the assessment of education] ( $1^{\text {st }}$ eds.). Trim Komunikata.

Tennant, A., \& Pallant, J. F. (2006). Unidimensionality matters (A tale of two Smiths?). Rasch Measurement Transaction, 20(1), 1048-1051.

Wang, C. B. (2011, JULY). 试探心理学理论关照下的写字教学 [ Psychological perspective in teaching and learning Chinese characters]. 中小学心理健康教育 [Mental Health Education in Primary and Secondary School], 181, 14-16. https://doi.org/10.3969/j.issn.1671-2684.2011.14.005

Wright, B. D. (1999). Common sense for measurement. Rasch Measurement Transactions, 13(3), 704.

Wright, B., \& Mok, M. M. C. (2004). An overview of the family of Rasch measurement models. In E. V. Smith Jr. \& R. M. Smith (Eds.), Introduction to Rasch measurement: Theory, models and applications (pp. 1-24). JAM Press.

Zandvliet, D. B. (1999). The physical and psychological environment associated with the classroom using new information technologies: A cross-national study [Doctoral thesis, Curtin University of Technology]. http://hdl.handle.net/20.500.11937/2124

Zhang, L. (2006, DECEMBER). 英语的"word"与汉语的”字“和”词“ [The difference between English “word” and the Chinese “character”]. 大庆师范学院学报 [Journal of Daqing Normal University], 26(6), 104-106. https://doi.org/10.3969/j.issn.2095-0063.2006.06.029 
Shiat Lu WONG, Nyet Moi SIEW, Chiow Thai SOON. Development of a children questionnaire for measuring Chinese character literacy learning satisfaction

PROBLEMS

OF EDUCATION

IN THE $21{ }^{\text {st }}$ CENTURY

Vol. 78 , No. 5, 2020

Zhang, X. P., Zhang, S. F., \& Zhou, Y. (Eds.) (2017). 小学识字写字教学指导 [Guide to teaching and learning Chinese character literacy in Chinese Primary schools] ( $1^{\text {st }}$ ed.). Beijing University.

Zhang, X. Z. (2016, JANUARY). 心理学视域下的写字教学策略设计 [On the design of the teaching of writing strategies in the perspective of psychology]. 集宁师范学院学报 [Journal of Jining Normal University], 1, 103-108. https://www.airitilibrary.com/Publication/ alDetailedMesh?docid=jnszxb201601024

Zhu, J. R. (2008). 班主任领导行为与学生学习主观幸福感的关系研究 [A study on the relationship between the leadership of form teacher and the learning subjective well-being of student]. University of Suzhou. http://cdmd.cnki.com.cn/Article/CDMD-10285-2008127081.htm

Received: May 05, 2020

Accepted: September 20, 2020

Cite as: Wong, S. L., Siew, N. M., \& Soon, C. T. (2020). Development of a children questionnaire for measuring Chinese character literacy learning satisfaction. Problems of Education in the $21^{\text {st }}$ Century, 78(5), 832-855. https://doi.org/10.33225/pec/20.78.832

\begin{tabular}{|ll|}
\hline Shiat Lu Wong & $\begin{array}{l}\text { Master Student, Faculty of Psychology and Education, University Malaysia Sabah, } \\
\text { Jalan UMS, 88400, Kota Kinabalu, Sabah, Malaysia. } \\
\text { Email: wongshiatlu@gmail.com }\end{array}$ \\
\hline $\begin{array}{l}\text { Nyet Moi Siew } \\
\text { (Corresponding author) }\end{array}$ & $\begin{array}{l}\text { PhD, Senior Lecturer, Faculty of Psychology and Education, University Malaysia } \\
\text { Sabah, Jalan UMS, 88400, Kota Kinabalu, Sabah, Malaysia. } \\
\text { E-mail: sopiah@ums.edu.my }\end{array}$ \\
\hline Chiow Thai Soon & $\begin{array}{l}\text { PhD, Lecturer, Center for the Promotion of Knowledge and Language, University of } \\
\text { Malaysia Sabah, Labuan International Campus, } \\
\text { Jalan Sungai Pagar, 87000 Labuan Federal Territory, Malaysia. } \\
\text { E-mail: soon@ums.edu.my }\end{array}$ \\
\hline
\end{tabular}

